Within Territory of Dnieper Basin. Indian Journal of Ecology. 2019. Vol. 46 (2). P. 402-407.

13. Бреус Д.С. Дослідження екологічного стану акваторії каховського водосховища. Водні біоресурси та аквакультура. 2020. С. 9-18.

14. Бреус Д.С. Світовий досвід ведення органічного землеробства та перспективи його розвитку в Україні. Таврійський науковий вісник. 2020. Т. 116. С. 198-206.

15. Лисецкий Ф.Н., Павлюк Я.В., Кириленко Ж.А., Пичура В.И. Бассейновая организация природопользования для решения гидроэкологических проблем. Метеорология и гидрология. 2014. № 8. С. 66-76.

16. Лисецкий Ф.Н., Пичура В.И. Оценка и прогноз изменений содержания гумуса в степных почвах с использованием геоинформационных и нейротехнологий. Российская сельскохозяйственная наука. 2017. № 1. С. 24-28.

17. Пичура В.И. Пространственно-временное прогнозирование изменений параметров агрохимических показателей мелиорируемых почв с использованием ГИС и нейротехнологий. Агрохімія і трунтознавство. № 78. С. 87-95.

18. Терехин Э.А., Пилипенко Ю.В., Пичура В.И., Чепелев О.А. Использование данных дистанционного зондирования земли и нейротехнологий для совершенствования мониторинга лесных массивов. Агроекологічний журнал. 2013. № 4. C. 41-47.

UDC 597.556

DOI https://doi.org/10.32851/2226-0099.2021.122.47

\title{
BIOLOGICAL CHARACTERISTIC OF THE BREAM ABRAMIS BRAMA L. IN THE DNIEPER-BUG MOUTH REGION
}

\author{
Kornienko V.O. - Candidate of Agricultural Sciences, \\ Associate Professor at the Department of Aquatic Bioresources and Aquaculture, \\ Kherson State Agrarian and Economic University \\ Olifirenko V.V. - Candidate of Veterinary Medicine, \\ Associate Professor at the Department of Ecology and Sustainable Development \\ named after Professor Yu.V. Pilipenko, \\ Kherson State Agrarian and Economic University \\ Rozhkov V.V. - Candidate of Agricultural Science, \\ Associate Professor at the Department of Aquatic Bioresources and Aquaculture, \\ Dnipro State Agrarian and Economic University
}

The effective functioning and development of the fishing industry of Ukraine in the economic space is determined not only by quantitative indicators, but also by the peculiarities of the economic relations formed at the end of the past - the beginning of the present century. The basis of the raw material base of the fishing industry of Ukraine, including the Kherson region, at the end of the 20th century was formed mainly due to catches of fish and seafood and, to a lesser extent, the products of intensive fish farming. At the same time, the fisheries of the Kherson region over the past decade have seen a steady decline in production and processes of reducing its potential, including the aging of the technical base, increasing resource and financial imbalances, leading to a decline in production. The situation is exacerbated by the increasing anthropogenic pressure on aquatic ecosystems, which has caused a sharp decline in fish catches of major industrial categories, additionally a few rare species have disappeared from industrial statistics. Natural fish populations adequately respond to the situation through 
adaptive reactions in the form of changes in the nature of ichthyologic mass formation, age structure, in productive indicators of species.

These studies highlight the issue of the state of productive capabilities of the local stock of bream of the Dnieper-Bug estuary. The initial data for the tasks are the results of field research conducted in the waters of the Dnieper-Bug estuary in 2014-2018 in the framework of the investigations of the Educational and Scientific Laboratory "Prospects of Aquaculture" of the Kherson State Agrarian and Economic University. Abramis brama L. bream of different ages were selected as the object of research.

The analysis of the productive abilities of female bream showed a depressed state of the population within the water area, which was the place of research. Absolute individual fertility of female bream depending on age ranged from 86.62 to 288.69 thousand eggs, its minimum value was observed for 4-year-old females with an average body length of $30.5 \mathrm{~cm}$ and a weight of $647.5 \mathrm{~g}$, the maximum value for 11-year-old females with a length of body weight $48.9 \mathrm{~cm}$ and weight $2047.1 \mathrm{~g}$. At the same time, for five years of observations, the fertility of female bream in some age groups decreased by $8.2-12.8 \%$. On the other hand, in comparison with the past century, the value of the absolute individual fertility of female bream in all age groups has decreased by 6.1-28.2\%. At the same time, a significant difference in the level of fertility was observed in both juvenile females and females of the oldest age, which clearly indicates the deterioration of the reproductive abilities of the population due to increased anthropogenic pressure on the bream population.

The research results significantly deepen the data on the current biological state of the industrial stock of bream of the Dnieper-Bug estuary.

Key words: Dnieper-Bug mouth region, bream, productivity indicators, fertility, catches, anthropogenic load.

Корніснко В.О., Оліфіренко В.В., Рожков В.В. Біологічна характеристика ляща Abramis Brama l. у Дніпровсько-Бузькому гирлі

Ефективне функиіонування і розвиток рибної галузі України в економічному просторі визначається не тільки кількісними показниками, але й особливостями сформованих економічних відносин у кіниі минулого - на початку нинішнього століття. Основа сировинноі бази рибної промисловості України, зокрема Херсонської області, у кінці ХХ століття формувалася переважно за рахунок уловів риби і морепродуктів і меншою мірою - продукиії інтенсивного рибнищтва. Водночас у рибному господарстві Херсонської області за останне десятиріччя спостерігається стійкий спад виробництва і відбуваються процеси зниження його потенціалу, зокрема старіння технічної бази; посилюються ресурсна і фінансова незбалансованість, щзо призводить до занепаду виробниџтва. Ситуація поглиблюється посиленням антропогенного навантаження на водні екосистеми, що спричинило різке падіння уловів риби основних промислових категорій, а рідкісні і нечисленні види взагалі зникли із промислової статистики. Природні популящії риб адекватно реагують на ситуацію через пристосувальні реакиії у вигляді змін у характері формування іхтіомаси, у віковій структурі, продуктивних показниках видів.

У дослідженні висвітлено питання про стан продуктивних можсливостей локального стада ляща Дніпровсько-Бузької гирлової області. Вихідними даними для виконання завдань роботи є результати польових досліджень, що здійснювалися протягом 2014-2018 рр. в акваторії Дніпровсько-Бузької гирлової області у межах теми Навчально-наукової лабораторії «Перспективи аквакультури» Херсонського держсавного аграрно-економічного університету. Об 'єктом дослідження обрано різновікові особини ляща Abramis brama L.

Проведений аналіз продуктивних здібностей самищь ляща показав пригнічений стан популяиії у межах акваторії, яка була місием досліджень. Абсолютна індивідуальна плодючість самиць ляща залежно від віку коливалася в межах від 86,62 до 288,69 тис. ікринок, ї̈ мінімальне значення відмічено для 4-річних самищь за середньої довжини тіла 30,5 см і маси 647,5 г, максимальне значення - для 11-річних самиць за довжиною тіла 48,9 см і масою 2047,1 г. Водночас за п'ять років спостережень плодючість самищь ляща за окремими віковими групами зменшилася на 8,2-12,8\%. Натомість порівняно з минулим століттям у сучасності величина абсолютної індивідуальної плодючості самиць ляща за всіма віковими групами зменшилася на 6,1-28,2\%. Значні відмінності за величиною плодючості спостерігались як у молодших за віком самиць, так і самиць найстаршого віку, що яскраво вказує на погіршення репродуктивних здібностей стада внаслідок посилення антропогенного тиску на популящію ляща.

Результати досліджень суттєво поглиблюють відомості про сучасний біологічний стан промислового стада ляща у Дніпровсько-Бузькій гирловій області.

Ключові слова: Дніпровсько-Бузька гирлова область, лящ, продуктивні показники, плодючість, улови, антропогенне навантаження. 
Formulation of the problem. In the context of the economic crisis, intensive fish farming requires significant costs associated with high prices for artificial feed, fertilizers and energy. In addition, Ukraine has a large area of continental reservoirs, reaching more than 1 million hectares, much of which is currently used very carelessly for fisheries purposes. This is due to inefficient management, ignoring the achievements and recommendations of fisheries science, lack or insufficient amount of fish stocking material of valuable fish species for the formation of highly productive ichthyocenoses $[1 ; 2 ; 3]$.

A particularly difficult situation is observed in large open and semi-closed waters estuaries, large reservoirs, lakes. These hydroecosystems have an incredibly significant bioproductive potential, represented by producers and consumers of different trophic levels, and the formed industrial ichthyofauna [4, 5]. However, at the beginning of the XXI century, the situation changed dramatically for the worse. A sharp decrease in the stock of planting material of valuable industrial species against the background of virtually uncontrolled industrial fishing, low efficiency of fisheries and reclamation measures, caused a sharp decline in stocks of major industrial fish species within these waters $[6 ; 7]$.

To improve the situation, it is necessary to conduct special research on the certification and grading of these waters, which will determine the bioproductive potential of reservoirs and identify ways to rationally use their fisheries in order to obtain a significant ammount of fish products. One of the research areas to be implemented is to study the potential of industrial fish species in terms of their ability to maintain their numbers at a high level. Taking into account the special importance in the formation of industrial fish products bream, which occupies the first positions in industrial statistics, our research was aimed at studying the biological parameters of the Lower Dnieper herd of this species of fish.

Analysis of recent research and publications. When studying the main biological indicators of an industrial herd, it is necessary to take into account the peculiarities of its structure. The structure of the herd is specific to the species and its individual local groups, it is a species and population property that reflects the nature of the relationship of individual populations with the environment [8]. In recent years, industrial populations of natural and transformed waters of Ukraine are under increasing pressure of environmental factors of anthropogenic nature $[2 ; 6 ; 10]$. The negative impact of these factors causes a sharp reduction in the number of populations and individual local herds of almost all valuable industrial fish species, including the Dnieper bream. Populations respond adequately to the situation through adaptive responses in the form of changes in growth, fertility, etc. [8]. A number of authors have shown that changes in the dynamic and functional indicators of ichthyocenoses can serve as macrocharacteristics of aquatic ecosystems, and the assessment of the main factors of formation and operation of industrial fish stocks - the basis for forecasting and regulation of fisheries $[11 ; 12]$.

There are also many publications on the effects of anthropogenic stress on certain biological indicators of the bream herd. It is shown that the influence of increasing industrial load, as the main anthropogenic factor, has a negative effect on the age structure of the Lower Dnieper bream [13]. The issues of changes in the sexual structure of bream [14], the nature of nutrition [15] and morphology of the species [16;17] under the influence of anthropogenic factors are covered to a lesser extent.

Changes in the biological state of the Dnieper bream herd due to the deterioration of the ichthyopathological situation have been sufficiently considered. Thus, it was found 
that the muscles of bream infested with Lamblia intestinalis contain less protein, fat, ash, calcium and phosphorus and have lower caloric content compared to healthy fish $[18 ; 19]$. Infection of fish L. intestinalis leads to a decrease in body weight of fish (without internal organs), to the loss of the edible part of the body of fish. In addition, the quality of muscles deteriorates compared to healthy fish, they increase the amount of moisture, reduce dry matter content, amount of fat and calories [19; 20-22]. There are slight changes in the chemical composition of the muscles of bream infected with plerocercoid L. intestinalis (water content, proteins, bicarbonates, lipids), compared with the high level of their energy reserves (such as triglycerides), which indicates the limited negative impact of L. intestinalis on physiological lentil loom.

Research methods. The research was guided by the principles of bioethics. The studies were carried out in accordance with the European Convention for the Protection of Vertebrate Animals used for Experimental and other Scientific Purposes ETS No. 123 and approved by the Science Council of the Kherson State agrarian and economic University. The initial data for the tasks are the results of their own field ichthyological research, which was carried out during 2014-2018 directly on water bodies in the research of the Educational and Scientific Laboratory "Prospects of Aquaculture" of the Kherson State Agrarian and Economic University. The object of the study were selected bream of different ages Abramis brama L., which belong to the local herd that lives within the waters of the Dnieper-Bug estuary. During the works, ichthyological samples were taken from catches of shuttered nets with an eye of $40-75 \mathrm{~mm}$, livers with an eye of 30-40 $\mathrm{mm}$, river seines.

The samples were subjected to processing, during which samples were taken for in-depth ichthyological analysis [23]. The sex of individuals was determined by the presence of secondary sexual characteristics, but for a more reliable analysis preferred the opening of the abdominal cavity. Absolute individual fertility was calculated by the weight method, and relative individual - as the ratio of absolute fertility to body weight of fish without viscera and body length [23].

Data are presented as mean values and standard error $(x \pm S E)$. Statistical analysis was performed by means of analysis of variance (one-way ANOVA). A value of $\mathrm{P}<0.05$ was considered statistically significant. Analysis of the variance of the influence of technological and environmental factors on the growth of larvae was carried out using the MANOVA.

The main task of this study is to assess the main biological parameters of the Lower Dnieper bream in modern conditions of increasing anthropogenic pressure on aquatic ecosystems.

Presenting main material. Reproductive capabilities of the species in these specific environmental conditions are one of the main factors determining the population size and the amount of replenishment of the industrial herd. Population reproduction is not disturbed at a certain intensity of fishing. This occurs when fishing eliminates the part of the herd to which the population is adapted (predation by predators, natural mortality).

In this case, the catch can be compensated by the regulatory mechanisms of the population, i.e. when the catch seems to be an element of the environment of the species. If the catch maintains a similar intensity and spawning and development conditions and the youth are not disturbed, the population can exist for many years. In populations of intensively caught commercial fish, the growth rate is higher and fertility is higher. However, in all fish populations with increasing fishing intensity, positive reactions are observed only to a certain extent. With a further increase in fishing intensity, the regulatory mechanisms of the population are disrupted, and it ceases to respond to further 
thinning of the herd, the main biological indicators deteriorate. In our studies, the productive properties of females of the Lower Dnieper herd of bream varied slightly over the years (Table 1 ).

According to the years of observations, the absolute individual fertility of female bream ranged from 82.62 to 288.69 thousand eggs with a general tendency to deteriorate the productive capacity of the herd. During the five years of observations, the fertility of female bream in certain age groups decreased by $8.2-12.8 \%$.

Table 1

Absolute individual fertility of female bream of the Dnieper-Bug estuary

\begin{tabular}{|c|c|c|c|c|c|c|c|c|}
\hline \multirow{3}{*}{ Years } & \multicolumn{10}{|c|}{ Age Groups } \\
\cline { 2 - 10 } & $\begin{array}{c}\mathbf{4}, \\
\mathbf{4}\end{array}$ & $\begin{array}{c}\mathbf{5}, \\
\mathbf{5 +}\end{array}$ & $\begin{array}{c}\mathbf{6}, \\
\mathbf{6 +}\end{array}$ & $\begin{array}{c}\mathbf{7}, \\
\mathbf{7 +}\end{array}$ & $\begin{array}{c}\mathbf{8}, \\
\mathbf{8 +}\end{array}$ & $\begin{array}{c}\mathbf{9}, \\
\mathbf{9 +}\end{array}$ & $\begin{array}{c}\mathbf{1 0}, \\
\mathbf{1 0 +}\end{array}$ & $\begin{array}{c}\mathbf{1 1} \\
\mathbf{1 1}+\end{array}$ \\
\hline 2014 & 92.11 & 98.50 & 124.75 & 141.68 & 186.15 & 230.42 & 270.18 & 292.82 \\
\hline 2015 & 89.32 & 90.36 & 113.24 & 139.05 & 181.47 & 223.56 & 265.29 & 284.55 \\
\hline 2016 & 85.31 & 91.89 & 117.37 & 137.56 & 177.16 & 221.47 & 258.43 & - \\
\hline 2017 & 82.65 & 90.15 & 108.73 & 134.03 & 170.39 & 215.64 & - & - \\
\hline 2018 & 83.68 & 92.75 & 111.61 & 136.29 & 180.11 & - & - & - \\
\hline Average: & 86.62 & 92.71 & 115.14 & 137.72 & 179.06 & 222.75 & 261.08 & 288.69 \\
\hline
\end{tabular}

The minimum indicators of absolute individual fertility of female bream were characteristic of the 2017 sample. At the same time, in general, there was a significant decrease in the number of age groups in the spawning part of the herd from 7-8 in 2014-2016 to 5-6 in 2017-2018. On the other hand, in comparison with 1965 [94], in all age groups, the value of the absolute individual fertility of female bream has now decreased from $6.10-25.5$ to $27.8-28.2 \%$. At the same time, a significant difference in the amount of fertility was observed in both juvenile females and females of the oldest age, which clearly indicates the deterioration of the reproductive abilities of the herd due to increased anthropogenic pressure on the bream population.

Given the specifics of this work, in our opinion, special attention should be paid to the analysis of the dependence of such an important biological indicator as the reproductive capacity of offspring on the dynamics of linear - mass indicators of the studied population (Table 2).

Table 2

Dependence of fertility of female bream on length and body weight $(x \pm S E, n=214)$

\begin{tabular}{|c|c|c|c|}
\hline \multirow{2}{*}{$\begin{array}{c}\text { Age } \\
\text { group }\end{array}$} & $\begin{array}{c}\text { Absolute individual fertility (AIF), } \\
\text { thousand eggs }\end{array}$ & \multicolumn{2}{c|}{ Relative individual fertility (RIF) } \\
\cline { 3 - 4 } & $86.62 \pm 11.65$ & $276.91 \pm 14.59$ & $133.86 \pm 10.14$ \\
\hline 4 & $92.71 \pm 12.14$ & $281.42 \pm 17.24$ & $98.17 \pm 11.51$ \\
\hline 5 & $105.14 \pm 22.18$ & $305.61 \pm 20.56$ & $95.23 \pm 10.67$ \\
\hline 6 & $137.72 \pm 24.52$ & $339.24 \pm 21.79$ & $101.75 \pm 10.08$ \\
\hline 7 & $179.06 \pm 32.25$ & $424.15 \pm 28.27$ & $114.75 \pm 12.30$ \\
\hline 8 & $222.75 \pm 34.89$ & $487.34 \pm 30.52$ & $131.18 \pm 14.83$ \\
\hline 9 & $261.08 \pm 42.08$ & $555.37 \pm 31.14$ & $140.75 \pm 11.68$ \\
\hline 10 & $288.69 \pm 43.51$ & $590.12 \pm 39.75$ & $141.03 \pm 15.18$ \\
\hline 11 & & \multicolumn{2}{c}{} \\
\hline
\end{tabular}


In relation to body length, the fertility of bream females also gradually increased with age from $276.91 \pm 14.59$ eggs $\mathrm{mm}$ in four-year-old females to $590.12 \pm 39.75 \mathrm{eggs} / \mathrm{mm}$ in the oldest females. In relation to the body weight of females, the fertility of female bream had slightly different characteristics. In the first years of puberty, the relative fertility of females of the bream herd gradually decreased from $133.86 \pm 10.14 \mathrm{eggs} / \mathrm{g}$ in four-year-old females to a minimum of $95.23 \pm 10.67 \mathrm{eggs} / \mathrm{g}$ in individuals aged six years. Subsequently, the relative fertility increased to the maximum values of $140.75 \pm 11.68-$ $141.03 \pm 15.18 \mathrm{eggs} / \mathrm{g}$ in the oldest females.

During the analysis of biological indicators of the bream population of the DnieperBug estuary region for the last decade, we have determined the size and age groups, which account for the main industrial load. These age groups were breams aged five to six years with a size of $32.9-34.9 \mathrm{~cm}$ (Fig. 1).

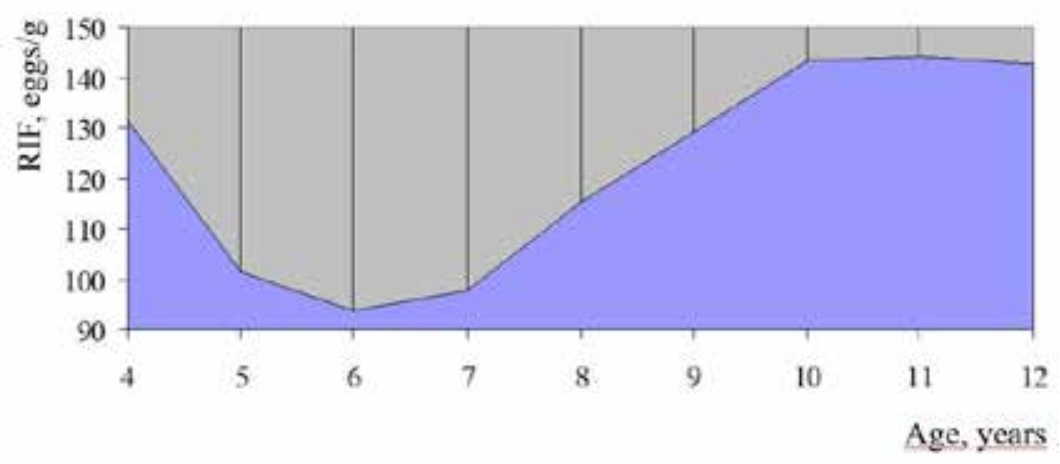

Fig. 1. Dynamics of relative fertility of female bream

At the same time, these age groups differed in the minimum values of relative fertility in $98.17 \pm 11.51$ and $95.23 \pm 10.67 \mathrm{eggs} / \mathrm{g}$, respectively.

Analyzing the data above, we can see that the absolute fertility of female bream is closely and positively correlated with the linear - mass characteristics, i.e. increases its ammount with the growth of the latter. The correlation coefficients range from 0.97-0.99.

Visually, the dynamics of changes in absolute individual fertility with body length is presented in Figure 2.

Thus, based on the results of the analysis of reproductive potentials of female bream in the Lower Dnieper population, we can assume the presence of a certain mathematically reliable relationship between the dynamics of absolute individual fertility and linear mass growth.

The determined regularities were used for detailed multifactor regression analysis, which resulted in obtaining a mathematical equation that combines by the method of least squares such pairs of features as absolute individual fertility $\left(\mathrm{y}_{\mathrm{AIF}}\right)$, linear dimensions $\left(\mathrm{x}_{1}\right)$, body weight $\left(\mathrm{x}_{\mathrm{m}}\right)$ and characterizes the degree communication between them (1):

$$
\mathrm{y}_{\mathrm{AIF}}=0.21 \mathrm{x}_{\mathrm{m}}-0.26 \mathrm{x}_{1}(1)
$$

The regression coefficient was $\mathrm{R}^{2}=0.99$, which confirms the fact that there is a close relationship between the considered pairs of traits. 


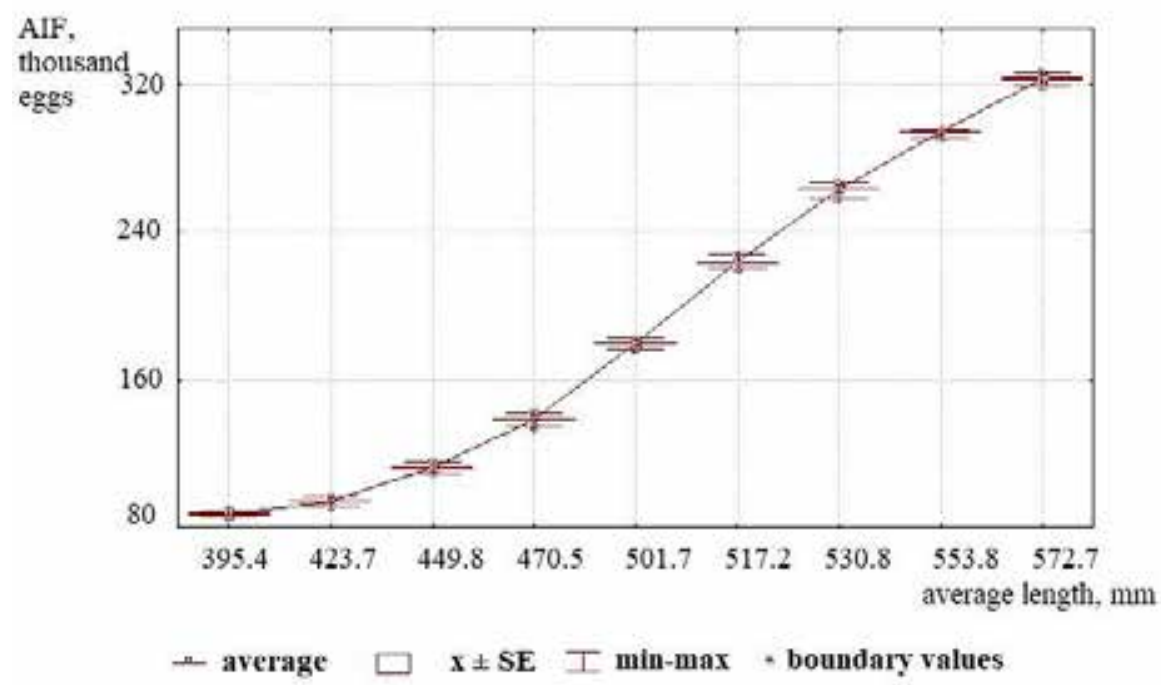

Fig. 2. Dependence of absolute individual fertility of female bream on body weight

Conclusions and suggestions. The analysis of the dynamics of the absolute individual fertility of female bream showed a depressed state of the population within the water area, which was the place of research. Absolute individual fertility of female bream depending on age ranged from 86.62 to 288.69 thousand eggs, its minimum value was observed for 4-year-old females with an average body length of $30.5 \mathrm{~cm}$ and a weight of $647.5 \mathrm{~g}$, the maximum value for 11-year-old females with a length of body weight $48.9 \mathrm{~cm}$ and weight $2047.1 \mathrm{~g}$. Relative fertility in relation to the linear size of bream with age increases from $276.91 \pm 14.59$ (in 4-year-olds) to $590.12 \pm 39.75$ eggs / $\mathrm{mm}$ (in 11-year-olds), in relation to body weight of females - initially decreases from $133.86 \pm 10.14$ (in 4- year-olds) to $95.23 \pm 10.67 \mathrm{eggs} / \mathrm{g}$ (in 6- year-olds), with a further increase to $141.03 \pm 15.18$ in 11 - year-olds.

\section{REFERENCES:}

1. Грициняк I.I., Третяк O.M. Пріоритетні напрямки наукового забезпечення рибного господарства України. Рибогосподарська наука України. Київ : ІРГ НААНУ, 2014. № 1. С. 5-20.

2. Пилипенко Ю.В., Оліфіренко В.В., Корнієнко В.О., Поліщук В.С., Довбиш О.Е., Лобанов I.А. Екологічні передумови раціонального ведення рибного господарства Дніпровсько-Бузької естуарної області. Херсон : Грінь Д.С., 2013. 190 с.

3. Кирилов Ю.Е., Корниенко В.А. Стратегия импортозамещения - мейнстрим развития рыбной отрасли Украины. Современные способы повышения продуктивных качеств сельскохозяйственных животных, птицы и рыбы в свете импортозамещения и обеспечения безопасности страны: сборник материалов Международной научно-практической конференции (г. Саратов, 14-16 мая 2015 г.). Саратов, 2015. C. 32-36.

4. Гейна К.М., Кутіщев П.С., Шерман І.М. Екологічна трансформація Дніпровсько-Бузької гирлової системи та перспективи рибогосподарської експлуатації: монографія. Херсон: Грінь Д.С., 2015. 300 с.

5. Коржов Є.І., Гончарова О.В., Кутіщев П.С. Аналіз можливих екологічних та соціально-економічних наслідків скорочення прісноводного стоку до Дніпров- 
сько-Бузької гирлової області. Матеріали Всеукраїнської науково-практичної конференції, присвяченої 80-річчю хіміко-біологічного факультету Тернопільського національного педагогічного університету імені Володимира Гнатюка: «Тернопільські біологічні читання. Ternopil Bioscience, 2020». Тернопіль : Вектор, 2020. C. 144-147.

6. Шерман І.М., Гейна К.М., Козій М.С., Кутіщев П.С., Воліченко Ю.М. Рибальство та рибництво трансформованих річкових систем півдня України: монографія. Херсон: Вид-во Гринь Д.С., 2016. 308 с.

7. Пилипенко Ю.В., Фалей В.Г., Лобанов И.А, Корниенко В.А. Организация акваполигонов для восстановления популяций ценных, эндемичных и исчезающих видов гидробионтов. Тезисы докладов Международной конференции: «Воспроизводство естественных популяций ценных видов рыб». Санкт-Питербург, 2010. С. 164-165.

8. Никольский Г. В. Тория динамики стада рыб. Москва : Пищевая промышленность, 1974. 447 с.

9. Веремеєнко С. І., Мосніцький В. О. Біологічна меліорація евтрофованих штучних гідроекосистем Західного Полісся України на прикладі Хрінницького водосховища. Вісник Житомирського національного агроекологічного університету. 2014. № 1(41), т. 3. С. 213-222.

10. Шевченко І.В., Коржов Є.І., Кутіщев П.С., Гончарова О.В., Шевченко В.Ю. Вплив абіотичних факторів на морфологічну варіабельність личинок Fleuria lacustris Kieffer, 1924 (Diptera, Chironomidae). Гидробиологический журнал. 2020. Том 56, № 3 (333). C. 15-23.

11. Бузевич И. Ю., Захарченко И. Л. Водохранилища Украины: перспективы рыбохозяйственного использования. Рыбоводство и рыбное хозяйство. 2013. Вып. 3. С. 35-41.

12. Білик Г.В., Коржов С.І. Огляд основних аспектів впливу кліматичних змін на сучасний стан іхтіофауни Дніпровсько-Бузької гирлової області. Збірник наукових праць: Наукові читання, присвячені Дню науки. Екологічні дослідження Дніпровсько-Бузького регіону. ВиП. 12. Херсон, 2019. С. 3-10.

13. Лобанов I.А. Лінійно-вагова характеристика ляща пониззя Південного Бугу та Бузького лиману. Таврійський науковий вісник. Херсон: Айлант, 2008. Вип. 58. C. 340-345.

14. Лобанов I.А. Основні біологічні особливості ляща Дніпровсько- Бузького лиману. Матеріали II Міжнародної іхтіологічної науково-практичної конференції: «Сучасні проблеми теоретичної і практичної іхтіології». Севастополь, 2009. C. $89-90$.

15. Лобанов І.А., Пилипенко ЮВ., Корнієнко В.О. Особливості живлення ляща у преднерестовий період у пониззі Південного Бугу і Бузькому лимані. Рибогосподарська наука України. 2009. № 1. С. 80-83.

16. Geina K. Analysis of the morphological variability of the bream (Abramis brama Linnaeus, 1758) Dnipro-Buh river mouth system. Scientific Journal «ScienceRise: Biological Science». 2018. № 6 (15). P.9-14.

17. Лобанов I.А., Пилипенко ЮВ., Корнієнко В.О. Морфологічна характеристика стада ляща Abramis Brama пониззя Дніпра. Таврійський науковий вісник. 2012. Вип.79. С. 204-210.

18. Оліфіренко В.В., Корнієнко В.О., Оліфіренко А.А. Особливості паразитофауни промислових риб в окремих ділянках Дніпровсько-бузького лиману. Воднi біоресурси та акваультура. 2020. Вип. 1. С. 35-43.

19. Оліфіренко В.В. Залежність гельмінтофауни риб від екологічних особливостей водойм. Таврійський науковий вісник: науковий журнал. 2011. Вип. 77. С. 195-199.

20. Оліфіренко В.В. Екологія гельмінтів риб Дніпровсько-Бузького лиману. Таврійський науковий вісник: науковий журнал. 2012. Вип. 78. С. 155-157. 
21. Воліченко Ю.М., Безпалова Л.Е., Оліфіренко В.В. Сезонні зміни гельмінтофауни деяких промислових риб дельти Дніпра. Таврійський науковий вісник: науковий журнал. 2011. Вип. 77. С. 191-194.

22. Оліфіренко В.В., Козичар М.В., Воліченко Ю.М. Якісна і кількісна характеристика гельмінтофауни промислових видів риб Дніпровсько-Бузької естуарної екосистеми. Таврійський науковий вісник: науковий журнал. 2012. Вип. 82. C. 181-185.

23. Пилипенко Ю.А., Шевченко П.Г., Цедик В.В., Корнієнко В.О. Методи іхтіологічних досліджень: навчальний посібник. Херсон: Олді-плюс, 2017. 432 с.

\author{
УДК 677.862.5 \\ DOI https://doi.org/10.32851/2226-0099.2021.122.48
}

\title{
ЕКОЛОГІЧНІ ПРОБЛЕМИ В ТЕКСТИЛЬНІЙ ПРОМИСЛОВОСТІ
}

\author{
Резнікова В.В. - к.т.н., старший викладач кафедри науки про Землю та хімії, \\ Херсонський державний аграрно-економічний університет
}

Відомо, щуо через недосконалість технологї в навколишнє середовище щзорічно потрапляють сотні мільйонів тонн рідких, твердих і газоподібних відходів, які завдають непоправну шкоду довкіллю. За підрахунками спещіалістів, через нераціональну діяльність людини на землі вже втрачено понад півмільярда гектарів ріллі, дві третини лісів, понад 250 видів тварин і птахів. Ще 600 видів тварин занесені в Червону книгу, тому що перебувають на межі повного зникнення. Під дією забрудненого навколишнього середовища відбувається руйнування природних ландшафтів, окислення трунтів, отруєння й загибель рослинності, тварин, риб і птахів, змінюється клімат, руйнується озоновий щзит, який захищає нашу планету від сонячної радіації. Кількість кисню, яку витрачає людина для технічних потреб, наразі дорівнює його відтворенню на нашій планеті. Такий розвиток технології може призвести до зниження концентрації кисню в атмосферному повітрі, щуо спричинить катастрофічні наслідки. Забруднення навколишнього середовища завдає непоправну шкоду здоров'ю людини.

Забруднення довкілля чинить негативну дію не лише на людей, які живуть сьогодні, але й завдає шкоду прийдешнім поколінням. Серед багатьох речовин, які забруднюють природне середовище, виокремлюють активні мутагенні агенти, які за потрапляння в організм людини призводять до зміни спадкового матеріалу на хромосомному й генному рівнях, щзо зрештою спричинює ріст генетичних аномалій серед населення.

Екологічні проблеми текстильної промисловості стосуються переважно вирішення завдань, пов 'язаних із утилізачією і регенерачією відходів виробництва: очищення стічних вод, створення системи оборотного водопостачання, очищення від пилу повітря робочої зони тощо. Застосування нових оздоблювальних засобів і сучасного устаткування дозволяє надати текстильним матеріалам властивості, які забезпечують комфорт, сприятливі для людини санітарно-гігієнічні умови та полегшують догляд за готовими виробами в побуті.

На жаль, іншому аспекту екологічних проблем текстильної промисловості - екологічному контролю самої текстильної продукиії-присвячено порівняно малу кількість робіт.

Ключові слова: технологї̈, забруднення, навколишнє середовище, икода здоров'ю людини, екологічна проблема.

\section{Reznikova V.V. Ecological problems in the textile industry}

It is known that due to the lack of technology hundreds of millions of tons of liquid, solid and gas-like wastes are discharged into the environment every year, causing unjustified harm to the environment. Specialists estimate that over two billion of hectares of land, two thirds of the forest, over 250 species of animals and birds have already been lost due to human activity. Another 600 species of animals are included in the Black Book, as they are on the verge of extinction. Under 